\title{
The History of Historiography and the Challenge of the Linguistic Turn*
}

\author{
Rogério Forastieri da Silva \\ rforastieri@gmail.com \\ Teacher \\ Colégio Etapa \\ Avenida Liberdade, 1046 \\ 01502-001 - São Paulo - SP \\ Brazil
}

\begin{abstract}
This exposition examines the relationship between the history of historiography and the linguistic turn, the latter being considered a challenge to the former. At first we attempt to define the meaning of "the viewpoint of the general history of historiography" by taking the history of historiography in its entirety from the Greeks to the present, thereby undermining the credibility of self-proclaimed "ruptures", "epistemological cuts", "revolutions", "mutations" and "new histories" in the recent developments of the general history of historiography, and thus questioning the "scientific" status of the discourse history. In the second section we try to depict the linguistic turn and the nature of the "challenge" it poses to the history of historiography. In the third section, with examples from Hans Ulrich Gumbrecht and Peter Englund, we qualify the role of Hayden White in the formulation of this challenge and its consequences for the practice of the discourse history. The conclusion resumes the arguments of Siegfried Kracauer, Arnaldo Momigliano, Johan Huizinga, Carlo Ginzburg and Hayden White (his in 2011), which combine to reinforce the importance of 906 considering the entirety of the general history of historiography when dealing with the discourse history, conceived as part of an "intermediate domain" that aspires to a scientific status (the commitment to the truth), but which cannot break free from the construction of collective memory or the settling of accounts with the past, hence the approximate nature of historical knowledge.
\end{abstract}

\section{Keywords}

History of historiography; Linguistic turn, Historical knowledge.

Received in: 9/17/2013

Approved in: 7/1/2014

* I would like to thank Ebal Martins Diniz Junior, PhD, for translating this paper into English. 
The title of this exposition concerns two different topics, namely the history of historiography and the linguistic turn (the latter being considered a challenge to the former). Now this "challenge" could be portrayed as an affront to be redressed in a duel or as the elicitation of a response. Supposedly there would be an established older object - the history of historiography - whose comfort zone began to be questioned by the more recent linguistic turn. Let us therefore try to characterize them and then speculate on the nature of the provocation and their possible answers.

\section{The Viewpoint of the General History of Historiography}

At the outset, a formal procedure is in order, so that misunderstandings should not cloud our topic. It therefore behoves us to propose the following nomenclature:

- H1 - Event history, in other words, all human events, at any time, in any space (characterized therefore by the infinity of objects);

- H2 - Discourse history, which is the work proper of the historian, the fragmentary account of human events; it makes use of narrative with the purpose of reconstructing them with a view to the constitution of a social memory;

- H3 - Historiography, or the history of discourse history, the several ways of writing this fragmentary account, in its most diverse modalities, throughout time;

- H4 - History of the histories of historiography, that is to say, the historiography of the histories of historiography.

Our focus is accordingly on the relationship between the discourse history $(\mathrm{H} 2)$ and the history of the discourse history $(\mathrm{H} 3)$, which we shall call the history of historiography.

Considering the modern general historiographical studies, there is some consensus among established authors (CROCE 1973; HAY 1977; KELLEY 1991) that the first concerted effort to write a general history of historiography was made by the Swiss historian Eduard Fueter (1876-1928) who in 1911 published a history of modern historiography ranging from the Renaissance to the late nineteenth century (FUETER 1914). From then on, i.e. from the Belle Époque, this historiographical production was no longer present only in bibliographies (LANGLOIS 1896), or in histories of literature and literary genres (ALBERT 1883; ROMERO 1888; LÉVRAULT 1905) and came to occupy a specific place within the historical production itself.

From a thorough examination of general histories of historiography it was possible to observe what we could call a change in the structure and content thereof, as over time they ceased to be associated with or engaged in the formation of "national historiographies" as in accordance with the pioneering model of history of history used by Eduard Fueter and began to include a wide variety of approaches and themes (IGGERS 1975; BREISACH 1983; BOURDÉ; MARTIN 1983; KELLEY 2006; BURROW 2008). As is well known history as 
an academic discipline is something directly associated with the formation of nation states, beginning in the late eighteenth century (BERGER; DONOVAN; PASSMORE 1999).

Thus, with an overview of the history of discourse history from the Greeks to the present day, we realized that, instead of considering only discontinuities in the writing of history that, as a rule, are libelled variously ["mutation" (CARBONELL 1976), "rupture", "epistemological cut", "revolution" (BURKE 1990)] in the history of historiography, it was possible to contemplate this insistence on emphasizing such discontinuities and, with greater serenity, to evaluate the nature of this succession of "historical schools", "historical styles" or, more simply, the various modes of writing discourse history.

The aforementioned study has shown us how often each new trend in the writing of history defines itself as "new", "modern", "post-modern" ${ }^{1}$, thereby opposing its predecessors by using a variety of labels to categorize them, such as "descriptive", "factual", "positivist" or "historisante" (FEBVRE 1992c, p. 114118), "traditional", "official", "outdated", "dated". It would appear that this list, by no means exhaustive, now includes "Marxist" history and may include other names in the future as well.

As a form of legitimization, of defining one's own identity, or as an attempt to transcend the former ways of writing history, the prevailing way - by dint of what is sometimes called "historical school" - compels its harbingers to caricature and view with contempt previous manifestations and to introduce themselves as 398 self-proclaimed representatives of a "new-history". Incidentally, this is ancient epithet, found since the fourth and fifth centuries in Zozimo - Historia nea, and in today's Nouvelle histoire (MONTELATICI 1916, p. 44; MOMIGLIANO 1987; NORWICH 1992; BROWN 1995). Currently, besides the adjective "new", other words and affixes have been added, such as the several "posts" and "turns" of historiography, like the present linguistic turn.

It is significant that, in general, the latest fad in the field of historiography will consistently endeavour to oppose preceding historiographical works, thus revealing the derogatory purpose of despising erstwhile breakthroughs. This establishing of "founding reports" of "new histories" has another harmful effect. The new generations of historians, by reason of those labels, end up failing to carefully examine those previous works and to situate them in the historical context in which they were produced; ultimately, they cease to realize the historicity of the writing of history itself.

Note, for example, Lucien Febvre's zeal to specify what was historically proper of Rabelais" own "religion" (FEBVRE 1968), since, according to the historian, documents were not enough to identify the character as an atheist; thus the historical account of the context in which Rabelais lived contrasts significantly with the ahistorical treatment Febvre gives to Charles-Victor Langlois and Charles Seignobos, authors of Introduction aux études historiques (1898) (LANGLOIS;

1 This formulation of the characteristics of postmodernity is attributed to Jean-François Lyotard (Lyotard 1979). It is worth remembering, however, that twenty years before, there already was some formulation about them. See: MILLS 1965, p. 180. 
SEIGNOBOS 1992). Lucien Febvre seems to ignore, in relation to them, the reason so much importance was given to document forgery. In the preface to a new edition of that Introduction, Madeleine Ribérioux sensibly underscores the importance of the issue, as the authors lived in the same period of time of the Dreyfus Affair when a glaring miscarriage of justice and a "legitimized" injustice notoriously took place precisely because of the use of forged documents.

Thus, "outmoded" past historians are often mentioned, but seldom the object of a more comprehensive study - for instance, who would take the trouble to read Démocraties et capitalisme (1848-1860) immediately after Lucien Febvre's fierce attacks on it? (POUTHAS 1948) ${ }^{2}$ - inasmuch as they have been clrearly labeled as "outdated". 3

Hence our exam of the aforementioned general histories of historiography has corroborated the idea that, in dealing with the history of discourse history, one must have as an important point of reference what we call "the vantage point of the general history of historiography". That perspective considers that any historiographical assessment must take into account all the history of historiography, from the Greeks - i.e. Herodotous - to the present (NOVAIS; SILVA 2011, p. 7-70; SILVA 2001).

Clearly, throughout the history of discourse history, there have been changes of approach, themes and expository styles. Nonetheless, we insist, not only do breaks occur, but also continuities and connections between the most current historiographical works and the historiography that preceeded them. Changes throughout the history of discourse history are therefore indicated in a recurrent fashion: whether discontinuities or continuities, and the ways "new histories" are heralded by their pionneers.

Another important implication to consider in assessing historiographical studies, from the vantage point of the general history of historiography, has a bearing on the very concept of discourse history. Evidently, this does not call for deconstructing the process by which this area of knowledge developed into an autonomous discipline aspiring to scientific status ever since the nineteenth century, but for an attempt to raise awareness about some aspects which we consider decisive for the frame of reference that we are seeking to specify, namely that the "linguistic turn" constitutes a "challenge" to the "history of historiography".

The worldwide impact that inventions, theories, conquests in science and consequent technologies had during the nineteenth century has yet in all likelihood to be extensively and properly assessed, but this one aspect can and should be emphasized: the labels "science" and its derivatives "scientific" and "scientist" made history and conferred upon their bearers an aura of credibility, reverence, respectability, authority and dignity that put them in a position"above suspicion".

\footnotetext{
${ }^{2}$ About this author and this work: FEBVRE 1992b, p. 99-103. The polemical author also took part in a prestigious collection of modern history: POUTHAS 1971, p. 389-415.

3 There is obviously an important exception when dealing with histographical studies of a particular historian such as: ROMILLY 1998; MOMIGLIANO 1966; EYCK 1982; ROBERTS 1987; PORTER 1988; FINK 1991; CANNADINE 1992; MELLOR 1993; MÜLLER 2003; MILLER 2007; BENTLEY 2011; PAUL 2011.
} 
Since then, the conquering of an identity, of a legitimacy, in short, the right of any area of knowledge to exist and be autonomous, demanded that it should be or look "scientific". The refusal to bestow such a scientific label upon a certain suitor would be tantamount to damnation; he became an outcast, no loger the object of attention except perhaps as an object of ridicule, the school dunce as it were. Some suitors suffered this grim fate, such as Franz Joseph Gall's (1758-1828) "phrenology", Francis Galton's (1822-1911) "eugenics", once deemed to be the "science of good breeding" (BOGARDUS 1965, p. 347-357) and also Lamarck (1744-1829) and Cesare Lombroso's (1836-1909) theories currently out of any consideration in the field of science.

We consider that it is within this historical context that we must understand the efforts of Karl Marx and Friedrich Engels to postulate a "scientific socialism" as opposed to "utopian socialism", as well as Sigmund Freud's insistence on asserting the "scientific" character of psychoanalysis. This attitude spread beyond the traditional branches of knowledge: suffice it to say that the formulator of what is called "Spiritism" defined it as "the science of observation".

Consequently, it could not have been different with history, which was achieving recognition, professorships, financial resources to hire teachears, for conducting research and publishing - in short, the discipline acquired citizenship rights, "droit à la ville". We can thus collect numerous instances of history being called a "science". Various authors, from different backgrounds, defend the 400 "scientific" status of history. Examples:

"We know only a single science, the science of history" [1845] - Karl Marx and Friedrich Engels (MARX 1965, p. 304).

"The science of history is the result of empirical perception, experience and investigation" [1858] - Johann Gustav Droysen (2009, p. 36).

"History is the science that investigates and expounds the facts concerning [...] human beings (...)" [1859] - Ernst Bernheim (1937, p. 47).

"History is and must be a science" [1862] - Fustel de Coulanges (1973, p. 179).

"... the present Introduction to historical studies has been conceived as an essay on the method of historical sciences" [1898] - Charles-Victor Langlois and Charles Seignobos (1992, p. 18).

"It has not yet become superfluous to insist that history is a science, no less and no more." [1902] - John Bagnell Bury (1973, p. 210).

"History is the science that attempts to describe, explain and comprehend the phenomena of the life [...] of men" [1921] - Wilhelm Bauer (1921. p. 38).

"History, science of man, science of the human past" [1933] - Lucien Febvre (1992a, p. 12).

"... History is a rigorous science ..." [1946] - Louis Halphen (HALPHEN 1948, p. 44). 
In our view, we historians seem to ignore the very historicity of the concept of history, then defined as a science, as an autonomous and academic discipline in the context of the scientific boom of the nineteenth century - we shall return to this idea afterward - hence, in dealing with the impact of the "linguistic turn" (as a challenge) upon the history of historiography, the point of view of the general history of historiography will be taken, thereby compassing the history of discourse history in its entirety.

\section{The Linguistic Turn}

The so-called linguistic turn was translated into Spanish and now into Portuguese as "giro linguístico". This expression came into general use within the context of Anglo-Saxon analytic philosophy tradition, and it indicated that many of the issues then regarded as philosophical were actually linguistic problems; in other words, philosophers could be using language to inadvertenly create problems otherwise nonexistent (QUINE 2011, p. 11-35). ${ }^{4}$

As regards the origin of this expression, there is a consensus that it was first used by Gustav Bergmann ${ }^{5}$ and that it inspired the title of the anthology organized by Richard McKay Rorty, who collected articles by well-established authors in linguistic philosophy with the aim of showing the "various ways in which linguist philosophers have viewed philosophy and philosophical method over the last thirty five years" (RORTY 1992, p. I).

Rorty's reflections came to include history when he called attention to the fact that one who uses language will not always be capable of ascertaining whether one is responding to a "compulsion of language" or a "compulsion of experience". In other words, when an interlocution is established there is a tendency to confuse the "compulsion of experience" - what is said about is real - with the "compulsion of language" - the way in which something is said about what said about what is real. In short, the question raised is whether the object of interlocution is a language issue or a matter of fact. In this way, an interest in the philosophy of language was awakened in relation to history, constituting what came to be called "philosophy of linguistic history" (RORTY 1979, p. 169 apud ANKERSMIT 2004, p. 124-129). Meanwhile developments and debates around structuralism and linguistics also resulted in an insistence of the non-referential use of language; Jacques Derrida and Roland Barthes stand out, among others.

Jacques Derrida draws attention to the fact that one's reading should not be reduced to reproducing the text; nor should it manipulate the text into something extraneous to itself, namely and indeterminate referent (methaphysical, historical, psychobiographical or any other kind of reality) or into a meaning outside the text whose content lay outside (written) language. Derrida then concludes that "there is nothing outside the text" ("Il n'y a pas de hors-texte"), in other words, language is autonomous, self-contained in itself (DERRIDA 2004, p. 194-195).

\footnotetext{
${ }^{4}$ I am grateful to Professor João Carlos Passoni for kindly suggesting this text.

5 "All linguistic philosophers talk about the world by means of talking about a suitable language. This is the

linguistic turn..." (BERGMAN 1964, p. 177 apud RORTY 1992, p. 8).
} 
Roland Barthes is even more adamant than Derrida. Focusing on the historical discourse, he states that a fact can only be defined in a tautological way: what is observed precedes that which is observable, yet the observable is only what is worthy to be remembered. According to Barthes, we thus arrive at what he considers the paradox of historical discourse: though a fact has only a linguistic existence ("le fait n'a jamais qu'une existence linguistique"), it constitutes the end of a discourse, as which is regarded as if it were a mere copy of another entity, namely what we call "real". So, from Barthes' perspective, the historical discourse would be the only one in which the referent is regarded as being external to the discourse and at once inacessible outside the same discourse (BARTHES 2012, p. 194).

For our purposes we could say that the linguistic turn has become a convenient label to express the idea that language is self-referential. Instead of saying that language is a means whereby one can refer to real-world objects (that is, a neutral instrument to point to, name and describe reality), language has a specificity of its own and is far from neutral.

In history the linguistic turn is commonly associated with Hayden White (PAUL 2011, p. 2; ANKERSMIT 2004, p. 119). Before him, it concerned the philosophy of linguistics, of Anglo-Saxon tradition (Richard M. Rorty), new developments in linguistics and French thinkers, particularly Jacques Derrida and Roland Barthes. White, inspired by these authors as well as by literary theory and literary criticism - specially the works of Northrop Frye (1973) - brought

102 this isssue into the field of history with his work on nineteenth century historians and philosophers Metahistory (WHITE 1992). His proclamation of the historical text as nothing but a "literary artifact" (WHITE 1994b, p. 97-116), from the standpoint of the linguistic turn, stirred mixed reactions from historians, thus constituting the "challenge" we shall proceed to discuss.

\section{Answers to the Challenge}

Once raised the issue of the linguistic turn in historiography, it can be said that intense debates took place (and it would be pointless here to recount each one of them in detail), particularly among those who remained critical of the use of the linguistic turn in historiography. ${ }^{6}$ Other authors, such as Martin Jay, have sought a compromise, alleging that it would be unfeasible to determine whether language is absolutely transparent or absolutely opaque and that this approach to the subject is extreme (JAY 1982, p. 86-110). There are also authors for whom the practice of history is no longer what it used to be, as we are now required to take the linguistic turn into account (MUNSLOW 1993) and yet other authors who endeavor to refer the linguistic turn beyond the frontiers of contemporary history (CLARK 2004).

It is now necessary that we indicate the manner in which the linguistic turn has been incorporated into history, not theoretically, but in the historian's

${ }^{6}$ Among many: MOMIGLIANO 1993, p. 304; HANDLIN 1979; NOVICK 1996; NOIRIEL 1996; EVANS 1999; SPIEGEL 2009. 
day-to-day research practices. We consider that Herman Paul's statement that Hayden White's influence on the practice and writing of history has been virtually "zero" is an exageration (PAUL 2011, p. 1-14). Ultimately, one of the messages the work of Hayden White leaves for historians is: "tell less" or "write less" and you will be writing "good" history; or "if you are really in the mood to write, move on to literature". Hence the works of Hans Ulrich Gumbrecht and Peter Englund have become excellent role models for authors who will listen Hayden White's message. For the purposes of illustration we shall proceed to examine one work of each author.

Hans Ulrich Gumbrecht is the author of In 1926, living at the edge of time. He attempts to be "non-narrative", that is to say, the book is not a tale that transmits the history of the year 1926 (GUMBRECHT 1999). In short chapters not in chronological, but alphabetical order, it is divided into three parts: "Arrays", "Codes" and "Codes collapsed". The first part includes snapshots of contemporary issues, such as "airplanes", "boxing", "cremation", etc.; the second part brings opposing pairs: "action vs. impotence", "center vs. periphery", "male vs. female", etc; the third part, casts doubt on some opposites: "immanence vs. transcendence", "male vs. female", "present vs. past", etc. At the beginning of the book Gumbrecht writes a "User's Manual" reminiscent to Julio Cortazar's Hopscotch (1963) and Milorad Pávitch's Khazar Dictionary (1984), informing the reader that he or she can begin to read anywhere in the text and hereafter either read on or jump back to a random section, thereby deliberately shuffling synchrony and diachrony and thus leaving to the reader's discretion the task of building their own 1926. A fourth part - "Frames" - discusses the study and teaching of history.

In The beauty and the sorrow: an intimate history of the First World War (ENGLUND 2012), Peter Englund follows the example of Gumbrecht and experiments with "non-narrative" writing; his intention is to show what it was like to live at that time. The table of contents shows the following sections: "To the reader", "Dramatis Personae", five chapters corresponding to the war years, "The end" and finally a closing chapter with the title "Envoi". From the outset the author introduces himself as an academic historian by profession and a sometime war correspondent (Balkans, Afghanistan, Iraq). As a historian, he once yearned to be present himself at the events he described; when, however, he was able to do it, he soon realized that being there is no guarantee of being able to understand an event. His book is therefore about the way the war was experienced by some of his contemporaries and not about the war itself, hence his choice of twenty individuals from different backgrounds and playing various roles, none of whom high in the hierarchies. The next section provides name, nationalities, occupations and ages, from the "American wife of a Polish aristocrat" to an "English nurse in the Russian army", and including a "Venezuelan cavalryman in the Ottoman army", etc. The chapters covering the war years follow, and they are always preceded by a chronology of the main events. In this way, he concocts a mixture of personal stories and the author's own interpretation. The last couple of pages - "Envoi" - reproduce two texts: 
a short speech made by a German priest and the testimony of a soldier who in 1925 , having faced the horrors of war, decides to become a politician. His name? Adolf Hitler.

There is no doubt that the gripping works of Gumbrecht and Englund absorb the reader from the first page, aind it could be argued that they carry out at least a part of the task they have undertaken, namely provide snapshots, as it were, of the atmosphere in the early years of the twentieth century. And yet, exit the authors - to allow the characters to speak for themselves - and the problems begin. The very choice of title, subject, documents and their order, and their comments on what is said in each document, betray their indisputable authorship; there is an underlying narrative, as if Gumbrecht and Englund had left to the reader the task of constructing it. But even this is a half-truth, since the reader would not be capable of constructing such narrative without their carefully select, commented and presented data. Deliberately or not, the absence of a chronology nothwithstanding, there is an order of sorts, inasmuch as the reader is provided with the elements needed to "create the narrative" from the "menu" offered by the authors. Such books are in fact authorial works. They might even propose an alternative way of producing narrative, which nonetheless does not preclude its own existence. We cannot therefore subscribe to these authors' claim that "non-narrative" history is feasible, let alone Englund's idea of "anti-history" (ENGLUND 2012, p.XIII).

In addition, we need to bear in mind that Derrida takes the propositions of the linguistic turn (Rorty) to extremes by absolutizing language (there is nothing outside the discourse); similarly, Gumbrecht pushes Hayden White's tenet to the limit (there is no difference between historical discourse and fictional discourse) by obliterating the historical discourse (when advocating the silence of the historian) and presenting only the documents. From our point of view, at the core of the problem is the relationship between historiography and the linguistic turn.

\section{Chiaroscuro}

Now is the suitable time to comment on Hayden White's premise that discourse history is a literary artifact. Essencially, any tipe of prose is indeed a literary artifact. But the author's meaning is undoubtedly more penetrating and implies the same opposing pair which comes up in Metahistory as well in his manifesto essay "The Burden of History" (WHITE 1994a, p. 39-63); the author opposes precisely "history as science" and the "literary artifact". So for him history is either science or literature, not both. Incidentally, not only White, but all authors who propose the scientific status of history follow the same two-valued logic.

The world of science and technology exists and evolves precisely by applying this logic. It is so powerful as to include humanities and shapes the way we see the world: "positive vs. negative", "0 vs. 1", "fiction vs. non-fictition", "nature vs. culture", "state of nature vs. civil society", "raw vs. cooked", "events vs. structure", and we could go on and on. But differently from other human 
"sciences", discourse history is not self-contained within this binary logic, exactly on account of its inescapable commitment to the construction of social memory.

Thus, despite the unquestionable efficacy of binary logic, we ought to make every effort to transcend it, especially when it concers human issues - history. We call to mind Shakespeare's Hamlet, who upon beholding his father's ghost tells his friend Horatio that there are more things in heaven and earth than are dreamt of in our philosophy. This statement warrants a couple of alternative readings. We are told that ghosts do exist, if not on stage, whenever we fail to settle accounts with the past, as individuals or nations. Take Turkey, where any mention of the Armenian Genocide is widely regarded as a crime; Japanese authorities painstakingly striving to conceal the violence and the massacres recently perpetrated against Chinese and Korean people retorically referring to a "Greater East Asia Co-Prosperity Sphere"; the United Nations Secretary General Kurt Waldheim, his accomplices in Austria and their conspiracy of silence about his less than accidental involvement with Nazism; the revisionist portrayal of the Holocaust as a total fabrication 7 ; the ever-present master-slave mentality in the ex-colonies of the American continent, where various forms of forced labor were (and remain) commonplace; in all these cases ghosts are ubiquitous and real. To settle accounts with the past means primarily to acknowledge them and to confront them. Denying their existence, sweeping them under the carpet or punishing those who dare to shatter the silence will not make them go away. But history can help us resolve these issues.

So if ghosts exist, could there be a viable alternative to binary logic when it comes to human affairs? Something undreamt of? Not everything is black or white, there are gray areas. And human imagination is capable of creating this alternative. That is the case of chiaroscuro in art, the doctrine of the "purgatory" ("neither heaven or hell") and religious thought itself, of any tradition, the distinctly human creation to help us succeed in our atempt to cut through transcendence in order to explain that which cannot be fathomed let alone handled by ordinary means.

This should likewise inspire us to seek such an alternative in addressing issues involving discourse history. In the first place, Hayden White's propositions seem rather deterministic, and so do those of linguistic turn proponents. The advances of linguistics and linguistic philosophy have led to the statement that language is an autonomous, specific, self-referential universe, a by-product of which would be the linguistic turn. Indeed, the very word "turn" ("giro") seems to presuppose that logic. A turn of one hundred eighty degrees: either we have scientific discourse or a fictional discourse, nothing in between. This approach is based on a somewhat hidden assumption that needs do be exposed.

We now wish to bring to mind an article by Carlo Ginzburg - "Clues: Roots of an Evidential Paradigm" (GINZBURG 1989, p. 143-179). Ginzburg makes a suggestion that should be considered. He begins his article by mentioning an art

\footnotetext{
7 For someone like Arnaldo Momigliano, whose parents were confined and executed in a Nazi extermination camp, it was very difficult to accept the idea that there is no available objectivity, that the historical text is a form of exercising power, a literary artifact and nothing else. Cf. STEINBERG 1991.
} 
critic who pretends to be Russian but is in fact Italian, and who considers museums "full of paintings with inexact attributions" but finds it difficult to trace an unsigned work to its real creator. The art scholar criticized the conventional wisdom in this field, saying it made no sense to depend on Da Vinci's smiles to determine the authenticity of a painting; instead of using the most conspicuous charcteristics of a painting to distinguish originals from copies, one should concentrate on details such as earlobes and fingernails, which would be "clues" as to the authenticity of a work. It was easier to copy a Da Vinci smile than one of his ears or fingers.

The same art critic, according to Ginzburg, inspired Freud to found his own "science", psychoanalysis. The psychoanalyst is not interested in outward signs, on what is plainly evident; rather, he focuses on faux pas, Freudian slips and unnoticed details. Ginzburg's whole reasoning goes further to consider "epistemes", "ruptures" or "mutations" not as abrupt transitions from "prior to writing" to "writing", but continuities as far as language is concerned. In other words, since the beginning of time, the first humans tried to identify the footprints or hair of animals for hunting (or fleeing) purposes, as well as cave paintings - these are all signs which meant something about something else that was no longer there, that is, a form of language. Such indices - to what was not present anymore - were a matter of life or death to a community. Thus language cannot be denied its indexing, referential quality. Vladimir Arseniev's hero, the hunter Derzu Uzala, was capable of identifying animals, movements and situations from tracks - or signs - left in the environment where he lived. He could read the language of nature (ARSENIEV 1989). ${ }^{8}$

Obviously - linguistics dispels any doubt about it - linguistic systems are autonomous. Linguistic philosophy shows likewise that linguistic expression does not necessarily refer to a particular referent (as Quine rightly pointed out in the aforementioned text, what would be the referent of the expression "the round square cupola?", but one cannot infer from this that "language is self referential", that it has nothing to do with the extralinguistic world (QUINE 2011).

Here we resume our initial reference to the insistence on defining history as a science, and how this approach to the problem presupposes the logical opposites "science vs. fiction". ${ }^{9}$ In discussing attempts to define history, Johan Huizinga identifies a problem with the above-mentioned definition offered by Ernst Bernheim and Wilhelm Bauer: by defining history as science, they exclude, ipso facto, Greek, Latin and Medieval historians, as well as a significant part of modern and contemporary historiography. Huizinga teaches that history, from Herodotus to the present, constitutes a creation of memory and involves temporality and the definition of identity, as a distinctive trait of Western societies. This is the reason that Huizinga accurately defines history as "the spiritual form whereby a culture settles accounts with the past" (HUIZINGA 1980, p. 95).

\footnotetext{
8 Magnificently explored in the Akira Kurozawa film [1975].

9 One should not overlook the implicit bias in the opposition. To say "This is fiction" or "This is literature" is rather like saying it is of little consequence. Incidentally, readers are referred to this beautiful and significant defense of literature, written by Mario Vargas Llosa, published in the newspaper O Estado de São Paulo on June 15, 2003: "Não é a literatura que envenena a vida" ("It is not literature that poisons life").
} 
Rather than lost in time, Huizinga's ideas live on and remain influential. In the same way, Siegfried Kracauer uses a parable to say that the historical discourse implies a search for meaning - it is not just a record, like annals and chronicles in the olden days, but the quest for intelligibility of each part within the whole, of an event within its own structure. Kracauer is actively engaged in learning "more about the constitution and significance of this controversial branch of knowledge". Having obtained freedom from metaphysics and theology, has history, he asks, become a science? So it claims to be, unquestioned. It can no longer be regarded as art, despite its literariness; nor is it a matter of impressionistic, subjective opinions. History, as we now know it, lies somewhere in a twilight zone created by its peculiar research and worldview. This go-between real is nonetheless invisible to the naked eye by reason of blinding deep-rooted traditional thinking, namely science and philosophy, as regards nature and mankind, inasmuch as they misrepresent historical research. Kracauer thus attempts to uphold the intrinsic legitimacy of this intermediate domain by calling it an ephemeral account of "the last things before the last", as the "last things" belong in science and theology (KRACAUER 1995, p. 15-16). ${ }^{10}$

In conclusion, let us return to our central character, Hayden White, the one who brought together the linguistic turn to history. A fine book about him was written by Herman Paul (mentioned earlier), who, for good reasons, chose to structure White's book in a chronological order. Paul undertakes a lenghtly tour of his intellectual biography of the author, from his initial training as a historian, his research into the history of the Church in Italy, his first historical works includin his impressive overview of the Greco-Roman cultural tradition (WHITE 1973), ${ }^{11}$ - the publication of his essays on the linguistic turn, which made him famous, to his present-day work as professor at the time the biography was published in 2011. Paul notes that White has not lost his combativeness - which he appropriately calls humanistic existentialism - in spite of the fact that he has certainly re-evaluated his ideas, as found in Metahistory. This is what strikes us as we read an interview conducted by Erlend Rogne in Rome in 2007 (WHITE 2009, p. 63-75), ${ }^{12}$ in which he defends or reconsiders some of his positions.

In the interview, Hayden White recalls his intellectual influences and discusses the relations between structure and event, the limits imposed by structures and the nondeterministic nature of the human condition, as we are continually called to make choices. He bears in mind what he learned from Aristotle: we perform conflictin roles in society; any role we choose to play well will inexorably undermine other roles we also need to occupy. This contradiction precludes us from living a "consistent, full" life.

In ethics, White defines himself as a "situationist": living in different situations, we cannot behave in the same way all the time. From structuralism he learned that each situation is always arbitrarily structured, just like language. The same applies to the rules that enable communication. To White, structuralism in

\footnotetext{
${ }^{10}$ I hereby acknowledge my debt to Professor Guillermo Zermeño Padilla.

${ }^{11}$ Incidentally, Metahistory was published in the same year.

12 For Hayden White's political views see also: ADAMA 2001, p. 12-17.
} 
no doubt important; yet, he keeps silent about changes in systematic structures, the main concern of post-structuralists such as Derrida, Foucault, Barthes and Lacan. Structuralism and post-structuralism would thus complement each other.

On the other hand, the author associates structuralism with the superstructure of market economy, which dictates the choices individuals make and at once leads them to think they are truly free. Here an important role is played by Jean-Paul Sartre's existencialism along with the Marxist view of history and society. White remembers that Roland Barthes once made him turn his attention to the theory of discourse and narrative and then to its tropological aspect; narrative discourse is adequate in some contexts but not in others. During the course of the interview, he thanks the interviewer for establishing a date for one of his writings, since he has changed his mind several times over the fifty years he has been writing. White also declares his predilection for modernism in literature due to its experimental work, thus questioning aesthetics of taste. As he points out, modernism results from the realization that the world we live in has no real essence or substance. Aristotelian substance theory is dead. Which implies the end of metaphysics and religion. Things are what they appear to be, there is no such things as an essence.

In short, the interview seems to point to a self-examination of sorts: Hayden White's formalist stance on the fundamental issue of the oppositions "event vs. structure" and "determinism vs. free will" no longer suffice to account for them, as he once defended in Metahistory, hence the importance of "mediations". ${ }^{13}$

As we tread this narrow path, might we suggest that it is not a meaningless 408 pursuit to reflect on the underlying binary oppositions which constrain discourse history; rather, we ought to take up the considerable challenge of thinking of this binary logic as part of what Kracauer has called "intermediate domain", an approach which embraces the whole of the history of historiography, from the Greeks to the present, as well as its paramount features, namely the construction of social memory and the settling of accounts with the past, two sides, indeed, of the same coin.

\section{Bibliographical References}

ADAMA, Frederick. Hayden White talks trash. Bad subjects, n. 55, p. 12-17, 2001. Disponível em: http://bad.eserver.org/issues/2001/55/white.html. Access in: Sept. 172013.

ALBERT, Paul. Histoire de la littérature romaine. Paris: Charles Delagrave, 1883.

ANKERSMIT, Franklin R. Historia y tropología: ascenso y caída de la metáfora. Traducido por Ricardo Martín Rubio Ruiz. México: Fondo de Cultura Económica, 2004 [1994].

ARSENIEV, Vladimir. Dersu Uzala. Traduzido por Aguinaldo Anselmo Franco de Bastos e Lucy Ribeiro de Moura. São Paulo: Veredas, 1989 [1923].

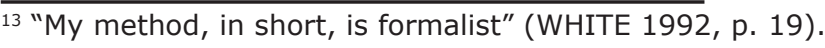


BARTHES, Roland. O discurso da história. In: O rumor da língua.

Traduzido por Mário Laranjeira. São Paulo: WMF Martins Fontes, 2012 [1984].

BAUER, Wilhelm. Introducción al estudio de la historia. Traducido por Luis G. de Valdeavellano. Barcelona: Bosch, 1921.

BENTLEY, Michael. The life and thought of Herbert Butterfield: history, science and God. Cambridge: Cambridge University Press, 2011.

BERGER, Stefan; DONOVAN, Mark; PASSMORE, Kevin. Apologias for the nationstate in Western Europe since 1800. In: (orgs.).

Writing national histories: Western Europe since 1800. London: Routledge, 1999, p. 3-14.

BERGMAN, Gustav. Logic and reality. Madison, WI: Wisconsin University Press, 1964.

BERNHEIM, Ernst. Introducción al estudio de la historia. Traducido por Pascual Galindo Romeo. Barcelona: Labor, 1937.

BOGARDUS, Emory S. A evolução do pensamento social. Traduzido por Ruy Jungmann. Rio de Janeiro: Fundo de Cultura, 1965 [1960]. (2 v.)

BOURDÉ, Guy; MARTIN, Hervé. Les écoles historiques. Paris: Seuil, 1983.

BREISACH, Ernst. Historiography: ancient, medieval and modern. Chicago: University of Chicago Press, 1983.

BROWN, Peter. Authority and the sacred: aspects of the Christianisation of the Roman world. Cambridge: Cambridge University Press, 1995.

BURKE, Peter. The French Historical Revolution: the Annales School, 19291989. Cambridge: Polity, 1990.

BURROW, John. A history of histories: epics, chronicles, romances and inquiries from Herodotus and Thucydides to the twentieth century. New York: Alfred A. Knopf, 2008.

BURY, John Bagnell. Inaugural lecture, Cambridge, 1902. In: STERN, Fritz (org.). Varieties of history: from Voltaire to the present. New York: Vintage, 1973.

CANNADINE, David. G. M. Trevelyan: a life in history. London: Fontana, 1992.

CARBONELL, Charles-Olivier. Histoire et historiens: une mutation idéologique des historiens français, 1865-1885. Paris: Privat, 1976.

CLARK, Elizabeth A. History, theory, text: historians ant the linguistic turn. Cambridge, MA: Harvard University Press, 2004.

COULANGES, Fustel de. Inaugural lecture, Estrasbourg, 1862. In: STERN, Fritz (org.). Varieties of history: from Voltaire to the present. New York: Vintage, 1973.

CROCE, Benedetto. Teoria e storia della storiografia. Bari: Gius. Laterza, 1973 [1913]. 
DERRIDA, Jacques. Gramatologia. Traduzido por Miriam Chnaiderman e Renato Janine Ribeiro. São Paulo: Perspectiva, 2004 [1967].

DROYSEN, Johann Gustav. Manual de teoria da história. Traduzido por Sara Baldus e Julio Bentivoglio. Petrópolis, RJ: Vozes, 2009.

ENGLUND, Peter. The beauty and the sorrow: an intimate history of the First World War. Translated by Peter Graves. New York: Vintage, 2012.

EVANS, Richard J. In defense of history. New York: W. W. Norton, 1999 [1997].

EYCK, Frank. G. P. Gooch: a study in history and politics. London: MacMillan, 1982.

FEBVRE, Lucien. De 1892 à 1933: examen de conscience d'une histoire et d'un historien. Leçon d'ouverture au Collège de France, 13.12.1933. In : Combats pour I'histoire. Paris: Albin Michel, 1992 [1953].

. Et I'homme dans tout cela? Sur un manuel. In: Combats pour I'histoire. Paris: Albin Michel, 1992a [1953].

. Sur une forme d'histoire que n'est pas la nôtre. L'histoire historisante. In: _. Combats pour I'histoire. Paris: Albin Michel, 1992b [1953].

. Le problème de l'incroyance au XVI'e siècle: la religion de Rabelais. Paris: Albin Michel, 1968 [1942].

FINK, Carole. Marc Bloch: a life in history. Cambridge: Cambridge University H10 Press, 1991 [1989].

FRYE, Northrop. Anatomia da crítica. Traduzido por Péricles Eugênio da Silva Ramos. São Paulo: Cultrix, 1973 [1957].

FUETER, Eduard. Histoire de I'historiographie moderne. Traduit de l'allemand par Emile Jean Marie, avec notes et additions de I'auteur. Paris: Félix Alcan, 1914 [1911].

GINZBURG, Carlo. Sinais: raízes de um paradigma indiciário. In:

Mitos, emblemas e sinais: morfologia e história. Traduzido por Federico Carotti. São Paulo: Companhia das Letras, 1989 [1986]. p. 143-179.

GUMBRECHT, Hans Ulrich. Em 1926: vivendo no limite do tempo. Traduzido por Luciano Trigo. Rio de Janeiro: Record, 1999 [1997].

HALPHEN, Louis. Introduction à I'histoire. Paris: Presses Universitaires de France, 1948 [1946].

HANDLIN, Oscar. Truth in history. Cambridge, MA: Harvard University Press, 1979.

HAY, Denys. Annalists ans historians: Western historiography from the Eighth to the Einghteenth centuries. London: Methuen, 1977.

HUIZINGA, Johan. En torno de la definición del concepto de historia. In:

El concepto de la historia y otros ensayos. Traducido por Wenceslao Roces. México: Fondo de Cultura Económica, 1980 [1946]. 
IGGERS, Georg G. New directions in European historiography. Hanover, NH: University Press of New England, 1975.

JAY, Martin. Should intellectual history take a linguistic turn? Reflections on the Habermas-Gadamer debate. In: LACAPRA, Dominick; KAPLAN, Steven L. (org.). Modern European intellectual history: reappraisals and new perspectives. Ithaca, NY: Cornell University Press, 1982, p. 86-110.

KELLEY, Donald R. Frontiers of history: historical inquiry in the $20^{\text {th }}$ century. New Haven: Yale University Press, 2006.

. Versions of history from Antiquity to the Enlighteenment. New Haven: Yale University Press, 1991.

KRACAUER, Siegfried. History: the last things before the last. Princeton: Markus Wiener Publishers, 1995 [1969].

LANGLOIS, Charles Victor; SEIGNOBOS, Charles. Introduction aux études historiques. Paris: Kimé, 1992.

. Manuel de bibliographie historique. Paris: Hachette, 1896.

LEVRAULT, Léon. Les genres littéraires: I'histoire, evolution du genre. Paris: Paul Delaplane, 1905.

LYOTARD, Jean-François. La condition postmoderne. Paris: Minuit, 1979.

MARX, Karl; ENGELS, Friedrich. A ideologia em geral. In: CARDOSO, Fernando Henrique; IANNI, Octávio (org.). Homem e sociedade: leituras básicas de sociologia geral. Traduzido por Roberto Schwarz. São Paulo: Nacional, 1965.

MELLOR, Ronald. Tacitus. New York: Routledge, 1993.

MILLER, Peter N. (org.). Momigliano and antiquarianism: foundations of the modern cultural sciences. Toronto: University of Toronto Press, 2007.

MILLS, Charles Wright. A imaginação sociológica. Traduzido por Waltensir Dutra. Rio de Janeiro: Zahar, 1965 [1959].

MOMIGLIANO, Arnaldo. El historicismo revisitado (1974). In: Ensayos de historiografía antigua y moderna. Traducido por Stella Mastrangelo. México: Fondo de Cultura Económica, 1993 [1977].

. On Pagans, Jews and Christians. Hanover, NH: Wesleyan University Press, 1987.

. The place of Herodotus in the history of historiography (1958). In:

Studies in historiography. New York: Harper, 1966.

MONTELATICI, Giovanni. Storia della letteratura bizantina (324-1453). Milano: Ulrico Hoelpi, 1916.

MÜLLER, Bertrand. Lucien Febvre, lecteur et critique. Paris: Albin Michel, 2003. 
MUNSLOW, Alun. Deconstructing history. London: Routledge, 1993.

NOIRIEL, Gérard. Sur la 'crise' de I’histoire. Paris: Belin, 1996.

NOVAIS, Fernando Antonio; SILVA, Rogerio Forastieri da. Introdução. In: ; __ (orgs.). Nova história em perspectiva. São Paulo: Cosac Naify, 2011. p. 7-70.

NOVICK, Peter. The 'objectivity question' and the American historical profession. New York: Cambridge University Press, 1996 [1988].

NORWICH, John Julius. Byzantium: the early centuries. New York: Alfred A. Knopf, 1992.

PAUL, Herman. Hayden White: the historical imagination. Cambridge: Polity, 2011.

PORTER, Roy. Gibbon: making history. London: Phoenix, 1988.

POUTHAS, Charles. Peuples et Civilisations: Histoire Générale. Volume 16. Démocraties et capitalisme (18480-1860). Paris: Presses Universitaires de France, 1948 [1941].

. The revolutions of 1848. In: The New Cambridge Modern History. Volume 10. The zenith of European power, 1830-1870. Cambridge: Cambridge University Press, 1971 [1960]. p. 389-415.

QUINE, Willard Van Orman. Sobre o que há. In:

De um ponto de

112 vista lógico: nove ensaios lógico-filosóficos. Traduzido por Antonio Ianni Segatto. São Paulo: Editora da UNESP, 2011 [1948]. p. 11-35.

ROBERTS, David D. Benedetto Croce and the uses of historicism. Berkeley: University of California Press, 1987.

ROMERO, Sílvio. História da literatura brasileira. Rio de Janeiro, 1888.

ROMILLY, Jacqueline. História e razão em Tucídides. Traduzido por Rosa Bueno. Brasília: Editora da Universidade de Brasília, 1998 [1956].

RORTY, Richard M. Introduction: metaphilosophical difficulties of linguistic philosophy. In: . (org.). The linguistic turn: essays in philosophical method with two retrospective essays. Chicago: The University of Chicago Press, 1992 [1967].

. Philosophy and the mirror of nature. Princeton: Princeton University Press, 1979.

SILVA, Rogerio Forastieri da. História da historiografia: capítulos para uma história das histórias da historiografia. Bauru, SP: EDUSC, 2001.

SPIEGEL, Gabrielle M. The task of the historian. Presidential Address. American Historical Review, fev. 2009. Disponível em: www.historians.org/info/ aha_history/spiegel.cfm. Access in: Sept. 172013.

STEINBERG, Michael P. (org.). The presence of the historian: essays in memory of Arnaldo Momigliano. History and Theory: studies in the philosophy 
of history. Middletown, CT: Wesleyan University. Beiheft 30, v. 30, n. 4, p. 1-4, 1991.

WHITE, Hayden .The Greco-Roman tradition. New York: Harper \& Row, 1973. - Meta-história: a imaginação histórica do século XIX. Traduzido por José Laurênio de Melo. São Paulo: EDUSP, 1992 [1973].

. O fardo da história. In: . Trópicos do discurso: ensaios sobre a crítica da cultura. Traduzido por Alípio Correia de Franca Neto. São Paulo: EDUSP, 1994a [1966], p. 39-63.

- O texto histórico como artefato literário. In: Trópicos do discurso: ensaios sobre a crítica da cultura. Traduzido por Alípio Correia de Franca Neto. São Paulo: EDUSP, 1994b [1978], p. 97-116.

. The aim of interpretation is to create perplexity in the face of the real: Hayden White in conversation with Erlend Rogne. History and Theory: studies in the philosophy of history. Malden, MA: Wesleyan University, v. 48 , n. 1, p. 63-75, 2009. 